\title{
Analysis and appraisal of fascine in Shahe ancient bridge ruins, Xi'an, Shaanxi, China
}

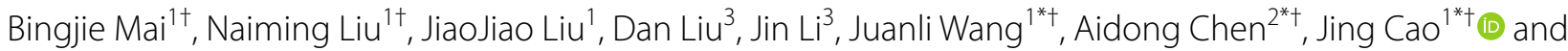
Yuhu $\mathrm{Li}^{1+}$

\begin{abstract}
Flood control initiated Chinese civilization. Chinese civilization has a long history, and Chinese ancestors invented "aquatic engineering technology" for flood control and water management, including the Fascine body, as early as two thousand years ago. The Fascine body is a structure used to protect the bank and prevent breaching of an ancient Chinese flood control project. Excavation of the Shahe ancient bridge ruins in Xi'an City, Shaanxi Province, China led to discovery of a Fascine body structure. Through ${ }^{14} \mathrm{C}$ dating, fibre, slice observations, infrared spectroscopy, $X$-ray diffraction, thermogravimetric analyses and SEM energy spectrum analyses of the fascine material, microbes in the structure and the surrounding soil were identified, the dominant microbial community was analyzed, and microbial diseases were controlled in a targeted manner. Research on the fascine bank ruins identified the width and length boundaries of the Shahe ancient bridge, determined the exact age of the Shahe ancient bridge, provided important materials for research on ancient bridges, river embankments and other ruins, and provided important clues for the traffic and layout around Chang'an during the Qin and Han Dynasties of Chinese history.
\end{abstract}

Keywords: Shahe ancient bridge, Fascine bank, Flood protection, Fascine body

\section{Introduction}

The Shahe ancient bridge ruins are located in the Shahe River Channel, Qindu District, Xi'an City, Shaanxi Province, China. In 1989, the Shahe ancient bridge Ruins were named one of China's "Top Ten New Archaeological Discoveries". The layout of the Shahe ancient bridge Ruins is clear, and the preservation of wooden structure bridge piles is complete. The piles are the largest and oldest large-scale wooden structure bridge piles in the world. Research on piles provides important physical materials regarding the history of bridge construction, the history of bridge development, and the history of ancient

\footnotetext{
*Correspondence: wangjuanli@snnu.edu.cn; 457895790@qq.com; jingcao@snnu.edu.cn

${ }^{\dagger}$ Bingjie Mai, Naiming Liu, Juanli Wang, Aidong Chen, Jing Cao and Yuhu

$\mathrm{Li}$, contributed equally to this work

${ }^{1}$ Engineering Research Center of Historical and Cultural Heritage

Protection, Ministry of Education, School of Materials Science

and Engineering, Shaanxi Normal University, Xi' an 710119, China

${ }^{2}$ Shaanxi Institute of Archaeology, Xi' an 710054, China

Full list of author information is available at the end of the article
}

metallurgy, and also provides important information on changes in the history of transportation in the Qin and Han Dynasties and the development and evolution of bridges. The Shahe ancient bridge ruins are located on the ancient river course. They bridge was the main hub crossing the Weihe River west of Chang'an City during the Han and Tang Dynasties. It was also an important traffic bridge in and out of Chang'an City on the Silk Road. Bridge piles were constructed of rare nanmus and other woods. Various forms of tiles, bronze ornaments, floor tiles and other cultural relics unearthed near the ruins demonstrate the importance of the Shahe ancient bridge. The neatly arranged bridge piles and large cast iron structures on the riverbed provide reliable physical evidence for restoration of ancient bridges from the Qin and Han dynasties in China, and they are rare and precious relics for researching the development and evolution of bridge construction in China [1]. When an unforeseen flood is caused by extreme precipitation or even a major, predictable flood occurs, the flood control

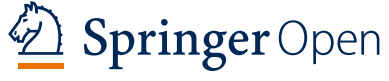

(c) The Author(s) 2022. Open Access This article is licensed under a Creative Commons Attribution 4.0 International License, which permits use, sharing, adaptation, distribution and reproduction in any medium or format, as long as you give appropriate credit to the original author(s) and the source, provide a link to the Creative Commons licence, and indicate if changes were made. The images or other third party material in this article are included in the article's Creative Commons licence, unless indicated otherwise in a credit line to the material. If material is not included in the article's Creative Commons licence and your intended use is not permitted by statutory regulation or exceeds the permitted use, you will need to obtain permission directly from the copyright holder. To view a copy of this licence, visit http://creativecommons.org/licenses/by/4.0/. The Creative Commons Public Domain Dedication waiver (http://creativeco mmons.org/publicdomain/zero/1.0/) applies to the data made available in this article, unless otherwise stated in a credit line to the data. 
capacity of the river channel may be affected, and the risk of accidents increases. River historical records, tree rings and cave animal analyses can aid in identifying river and lake traces [2-4].

The Fascine body is a structure used to protect the bank and block the rupture of ancient wood flood control projects. Living plant materials were also used in more sophisticated structures such as fascines and wattle fences [5-7]. These structures limited undermining caused by water flows at the bottom of the riverbank. They also limited erosion from streaming on the upper part of the riverbank by significantly reducing the bank's slope and creating physical barriers against surface runoff. They were made of soft materials such as reeds, bamboo, willow branches, soil and gravel, and tied with ropes to form cylindrical shapes, pressing the second fascine, third fascine, and fourth fascine on the outer surface of the first fascine to form a structure $[8,9]$. The use of a fascine is a powerful technical guarantee allowing the ancients to generate turbulent water. In 1600, Olivier de Serres described in "Théâtre d'agriculture et Ménage des champs" the use of "bushes attached to stakes and reeds" to protect the watersides of fish ponds from the impact of waves. In 1730, Forest de Bélidor recommended the use of fascines as "alternative stone paving" to limit undermining at the bottom of waterlocks [4]. Similarly, fascines have been widely used in ancient Chinese water conservancy projects. This technology has been used in many rivers, such as the Yangtze River, the Yellow River and the Huai River, as well as in sea ponds and wharf projects $[10,11]$. Especially in treatments of the Yellow River involving, emergency repairs of levees and blockage of ruptures, fascine bodies have been regarded as one most important engineering approaches $[12,13]$.

Fascine bodies were also found in the Shahe bridge ruins, indicating that fascine technology was also used in the Guanzhong area in Shaanxi Province, and this pushed the credible history of fascine use in China back to the Qin and Han dynasties. As a basis for further preservation of these fascine, it was necessary to analyse microflora colonization $[14,15]$. In this research, we identified and analysed the fascine materials found in the Shahe ancient bridge ruins in Xi'an, Shaanxi, and determined the differences between dominant microbial species and bridge pier microbial species to find an antifungal reinforcing agent for the fascine materials in a targeted manner, and provides a certain scientific basis for long-term preservation of the Shahe ancient bridge ruins (Fig. 1). Flood control initiated Chinese civilization [16]. Interactions between water and soil have been both a blessing and a curse at all times within living memory. On the one hand, people benefit from water resources; on the other hand, they must deal with the threat of flooding. To protect the land and enable beneficial uses such as irrigation and navigation, special measures are often needed to keep water levels within a certain range and achieve permanent stability. Construction of dikes to limit the waterway is an effective control measure $[17,18]$. During the ancient times, rivers were modified, if necessary, to minimize the damage caused by floods [19]. Study on Shahe

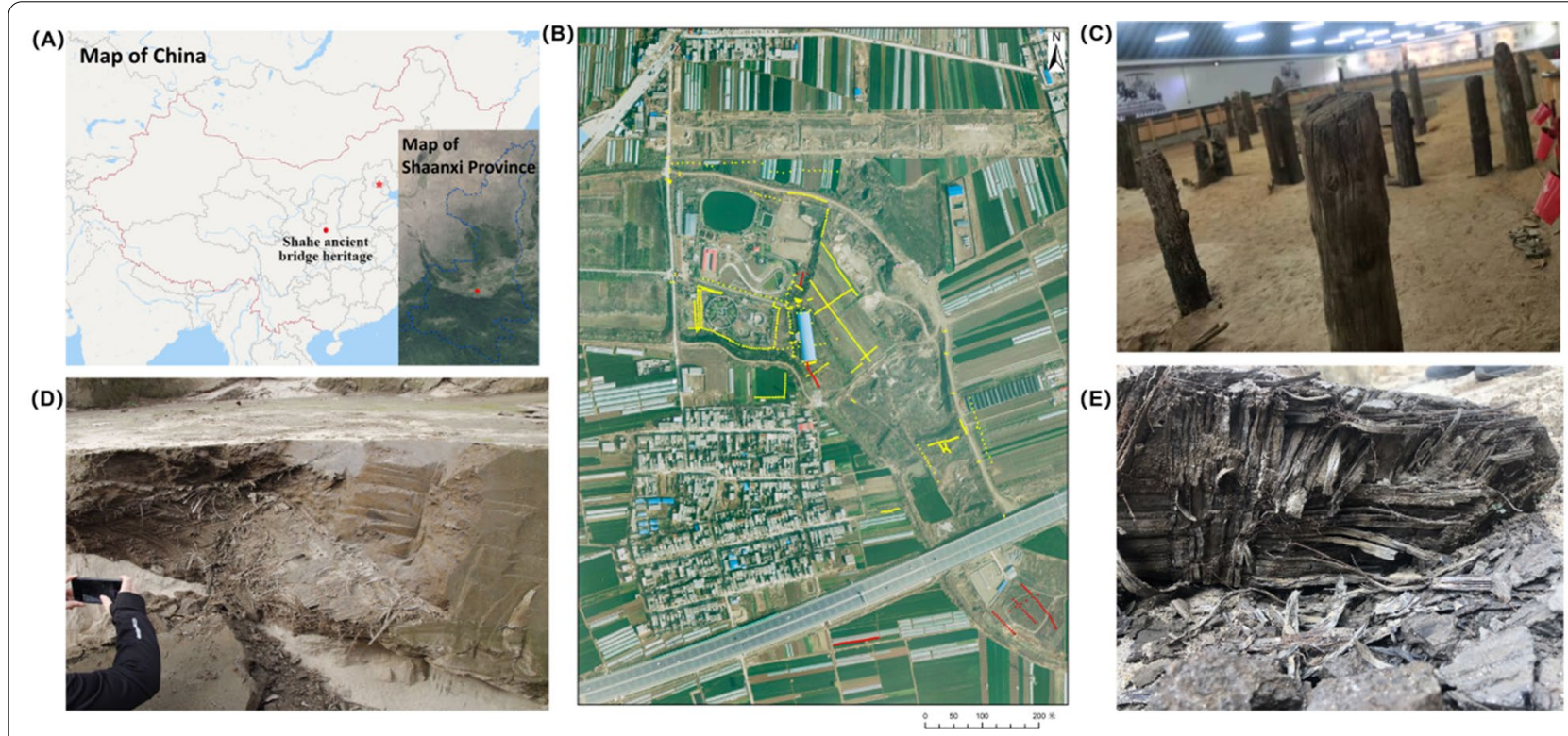

Fig. 1 The Shahe ancient bridge ruins and fascine bank ruins; A Location map of Shahe ancient bridge site; $\mathbf{B}$ Shahe ancient bridge site map from 19-20 years of exploration; C Shahe ancient bridge ruins; D Fascine bank ruins; E Unearthed woven material of the fascine body 
ancient bridge provides information on the status of the Qin and Han dynasties in the history of Chinese water conservancy, interprets the relationships between current banks and ancient river banks, establishes the length and scope of the ancient Shahe bridge to provide insight on the Qin and Han dynasties, and provides an important scientific basis for studying the traffic and layout around Chang'an City during the Qin and Han Dynasties.

\section{Materials and methods}

\section{Microscopic slice observations}

A small piece of sample was cut and embedded in epoxy resin after trimming. After the resin was cured, an ultrathin microtome (EM UC7, Leica company, Germany) was used to cut slices with thicknesses of 1-2 $\mu \mathrm{m}$. The slice was fixed on the stage, and an optical microscope (XWYVI, Zhuhai Hualun Paper Technology Co., Ltd., China) was used to observe the microstructure of the sample at $40 \times$ magnification.

\section{Infrared (FT-IR) absorption spectroscopy}

The sample was ground with an agate mortar to make approximately $2 \mathrm{mg}$ of powder, and the infrared spectrum was determined with a $\mathrm{KBr}$ tablet (Fourier transform infrared spectrometer, Nicolet is 10, Thermo Fisher company, USA). The spectral range was $4000-400 \mathrm{~cm}^{-1}$, the resolution was $4 \mathrm{~cm}^{-1}$, and the number of scans for the sample and background was 64 . The molecular structures of a sample were determined from the characteristic absorption peaks in the infrared spectrum for each functional group.

\section{$\mathrm{X}$-ray diffraction (XRD) analysis}

After the surface of the sample was polished and smoothed, X-ray diffractometry (D8, Bruker company, Germany) was used to compare the crystallinity of the Shahe sample with that of a modern sample. During testing the scan time was $21-30 \mathrm{~s}$, the scan range was $5-70^{\circ}$, the scan rate was $0.02 / \mathrm{s}$, the X-ray tube contained a $\mathrm{Cu}$ target, the radiant tube voltage was $40 \mathrm{kV}$, and the radiant tube current was $40 \mathrm{~mA}$.

\section{Thermogravimetric (TG) analysis}

$5 \mathrm{mg}$ of the sample was weighed, and a synchronous thermal analyser (TG209F1, Natzsch company, Germany) was used to generate a thermogravimetric curve of the Shahe sample to determine its preservation status. During testing, the protective gas was nitrogen, the temperature range was $35-900{ }^{\circ} \mathrm{C}$, and the heating rate was $10{ }^{\circ} \mathrm{C} /$ min.
Scanning electron microscopy and EDX spectrum analysis The sample was glued horizontally and vertically on the sample stage using conductive glue, and sprayed with gold, and SEM and energy spectrum observations and analyses were performed (SU3500, Hitachi company, Japan).

\section{Microbial analysis and identification}

The environment influences the distribution of microorganisms, and through the analyses of advantageous microbes, we differentiated the microorganisms of the bridge pier and fascine materials. The samples of bridge pier and fascine materials were placed in PDA medium and cultured $48 \mathrm{~h}$ (Aobox Biotechnology Co. LTD, Beijing, China); after the microorganisms grew, inoculation loops were used to pick a single colony and placed it in a sterile PDA, and this step was repeated, When only one kind of microorganism grew in the plate, the mycelium and spores are sprayed with gold on a conductive adhesive and photographed by scanning electron microscopy (SEM, SU-3500, Hitachi, Japan). Fungi were sent to Shanghai Parsono Biotechnology Co., Ltd. (Shanghai, China) for species identification.

\section{Data analyses}

SPSS 19.0 software (SPSS Inc, Chicago, IL, USA) was used for statistical analyses. Values are expressed as the means \pm standard deviation $(\mathrm{SD})$ of at least three independent experiments. Statistical comparisons were made using one-way analysis of variance, and multiple comparisons between groups were performed using Tukey's test, with $\mathrm{p}<0.05$ considered statistically significant and $\mathrm{p}<0.01$ considered highly significant.

\section{Results and discussion}

\section{Structure of the fascine body}

In water conservancy projects, "fascine" is used as a hydraulic construction; firewood, bamboo and wood, and other soft materials are woven into a flat structure, mixed with earth and stone, and rolled, as shown in Fig. 2A. Several fascine bodies are connected with ropes and piles and used as revetments or for blockage, closure and other projects [7]. The pictures taken of the Shahe bridge ruins are consistent with traditional craftsmanship. The silt block was wrapped in a mat-like weave and was related to a man-made river embankment. The silt layer is called a "Fascine bank", that is, a bank built with a fascine body. We marked the edges of each small block in Fig. 2B-E, and we preliminarily determined that the "fascine bank" range was the riverbank at that time, and the northern boundary of the bridge body was the newly discovered northernmost row of bridge piles. We 


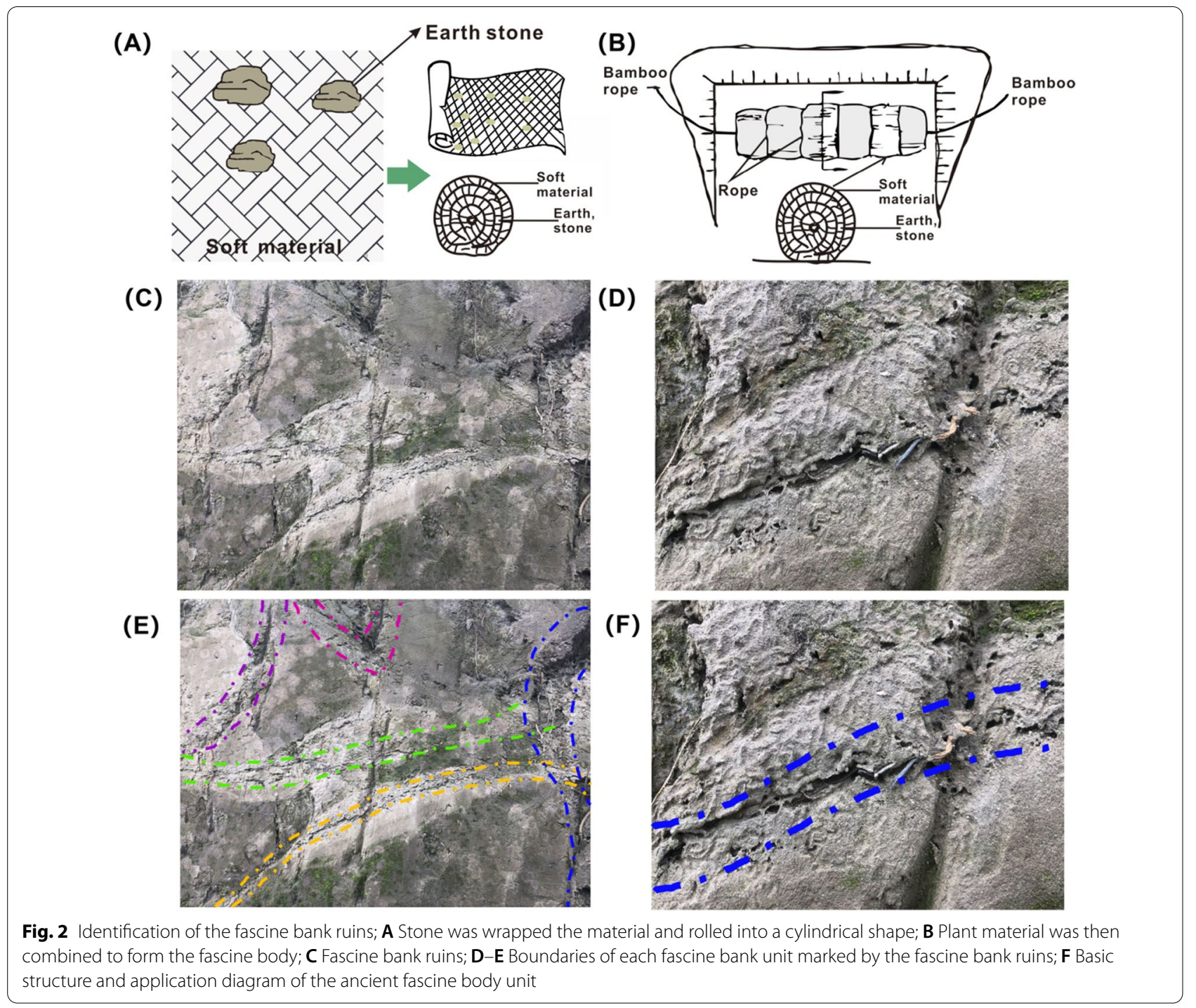

basically determined the length and scope of the No. 1 Shahe ancient bridge. According to a newly discovered silt layer accumulation and the range of bridge piles, the plane where the silt layer is located was preliminarily identified as the riverbank, and the northern edge of the bridge body was bounded by the newly discovered northernmost row of bridge piles. Excavation was carried out on the south side of the protection greenhouses and southward exploration was continued, but no new bridge piles were found. These results confirm that the width of the Shahe ancient bridge was $16 \mathrm{~m}$, and the northern end was $22 \mathrm{~m}$ away from the protection hall. In 1989, when the Shahe ancient bridge was excavated for the first time, the ${ }^{14} \mathrm{C}$ dating $[20,21]$ was used to determine the age of the No. 1 Bridge as approximately $2350-1910$ years ago. In this work, we dated two sets of braided fabric samples wrapped in a silt layer. The age were approximately
2210-2058 and 2230-2072, which were slightly later than those of the bridge piles, but the difference is not very large. The ${ }^{14} \mathrm{C}$ dating results represent the growth age of the sample, not the construction age (Table 1). In constructing bridge piles, it takes a long time for trees to be planted, grown and then felled for construction of the bridge piles, and there is often a large gap between the growth age and use age. It takes a long time for trees to grow until they are felled for use in constructing bridge piles. There is often a large gap between the age of growth and the age of use, but the soft materials used in the braids were mostly plants with shorter growth cycles; therefore, their growth ages are close to the age of use, and the dating results for the bridge pile and the braid generally differed by $100-200$ years, which is consistent with the time required for tree growth. The dating results for the fascine material, indicated that the construction 
Table $1{ }^{14} \mathrm{C}$ dating results

\begin{tabular}{|c|c|c|c|c|}
\hline \multirow[t]{2}{*}{ Number } & \multirow[t]{2}{*}{ Sample } & \multirow[t]{2}{*}{$14 C$ dating } & \multicolumn{2}{|l|}{ Calibration age } \\
\hline & & & $1 \sigma(68.2 \%)$ & $2 \sigma(95.4 \%)$ \\
\hline 1 & Wood & $2210 \pm 30$ & $\begin{array}{l}260-206 B C(33 \%) \\
320-275 B C(27.9 \%) \\
359-347 B C(7.3 \%)\end{array}$ & $371-199 B C(95.4 \%)$ \\
\hline 2 & Wood & $2180 \pm 30$ & $\begin{array}{l}354-291 B C(68.2 \%) \\
232-193 B C(23.5 \%)\end{array}$ & $361-168 \mathrm{BC}(95.4 \%)$ \\
\hline 3 & Braided fabric & $2130 \pm 30$ & 202-108BC (68.2\%) & $\begin{array}{r}210-52 B C(85.1 \%) \\
350-308 B C(10.3 \%)\end{array}$ \\
\hline 4 & Braided fabric & $2080 \pm 30$ & $\begin{array}{l}116-51 \mathrm{BC}(52 \%) \\
157-134(16.2 \%)\end{array}$ & $\begin{array}{c}190-38 B C(94.5 \%) \\
9-3 B C(0.9 \%)\end{array}$ \\
\hline 5 & Wood & $2170 \pm 30$ & $\begin{array}{l}352-297 B C(40.2 \%) \\
211-176 B C(24.3 \%) \\
228-221 B C(3.7 \%)\end{array}$ & $\begin{array}{l}360-155 B C(92.9 \%) \\
134-116 B C(2.5 \%)\end{array}$ \\
\hline 6 & Wood & $2300 \pm 30$ & $401-366 B C(68.2 \%)$ & $\begin{array}{l}406-356 B C(79.4 \%) \\
287-234 B C(16 \%)\end{array}$ \\
\hline
\end{tabular}

of the Shahe ancient bridge occurred during the transitional period between the Qin and Han Dynasties.

The Shahe ancient bridge demonstrates an important cultural practice and provides epic historical materials from the Qin and Han dynasties of China. In Fig. 3A, the three circles with Shahe ancient bridge as the centre represent, respectively, the scope of Shahe ancient bridge, the banks that it crossed and the urban spaces connected by the Shahe ancient bridge. The pictures show that the Shahe ancient bridge site was one of the most important transportation roads connecting the Wei River and Feng River. Based on the discovery of the fascine site, the evolution of the ancient Shahe river, the distribution of the site and the location of the bridge were confirmed, and the nature, age and function of the site as well as the location of the riverbank were determined clearly. The silt layer is derived from the banks of the river at that time, the plane of the bridge on the northern border is bounded with the newly discovered northernmost bridge pier, and the rest of the region remains with no bridge into the aquifer at the bottom of the bridge pier. For subsequent protection and to provide a basis for design, the bridge was at the same time in the "southwest silk road" and "desert silk road" fork mouth. It was the key connecting the northwest and southwest of Chang'an, the capital of Han Dynasty. Therefore, it is also known as the "First bridge of the Silk Road", which is of great value and significance for studies of the Silk Road.

Construction of bridges is closely related to the hydrological conditions of rivers. In the pre-Qin period, the climate was basically semiwarm and semihumid, and the annual precipitation level was relatively high, so the river water level was high, the flow was large, and the aquatic products were abundant. The Fengshui river, including the old Shahe bridge, was developed. Man's ability to transform nature was greatly enhanced by the spread of iron tools and cattle ploughs, and river irrigation projects flourished. To cope with and make use of this watery environment, the Guanzhong area of Shaanxi Province started the practice of building bridges very early.

The Shahe ancient bridge was originally built for the convenience of the Qin and Han emperors, who hunted in the upper forest, and later evolved into an important bridge across Feng river on the main traffic road from Chang'an to Bashu area. The area surrounding the site of the Shahe ancient bridge was densely populated with Qin and Han dynasty sites (Fig. 3B). In addition to the Xiwei ancient bridge site, the newly excavated Dongmafang site is located $2.5 \mathrm{~km}$ to the northeast of Shahe ancient bridge site. The Zicun site discovered in 2019 is similar in age to Dongmafang site and is $1.0 \mathrm{~km}$ away from Shahe ancient bridge site. Both sites are located on the north side of the ancient Feng River ancient, road and face the Shahe ancient bridge site from north to south. The site of Dayuancun on map was one of the palaces of Shanglin Yuan located south of Weihe river during the Western Han dynasty. Zhaolunzhuqian was the site of a coin production workshop in Shanglin Yuan. Hanjiaoting was the site of the local administrative body of the Han dynasty. During construction of Maoling tombs and silk Road projects, the Xiliucang site was used for the grain storage warehouse of the Han dynasty. The above ruins show that Shahe ancient bridge "functioned" as the Feng river ancient bridge in the area separated by the Feng river and Wei river. This was located at the ancient capital of the Qin and Han dynasties and in the grove on the west side of the bridge, and was 


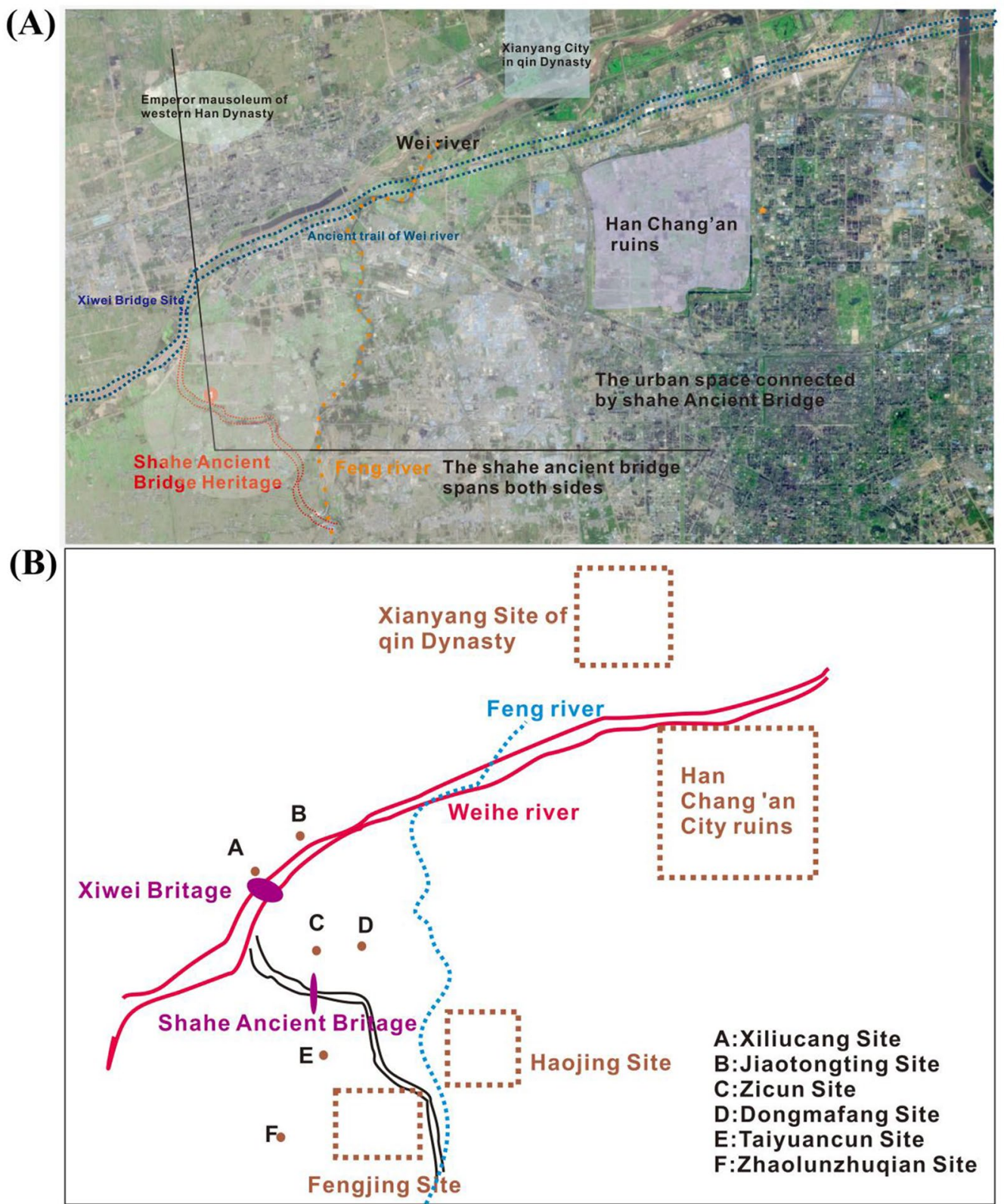

Fig. 3 A Spatial level of Shahe ancient bridge site landscape; B Distribution map of Qin and Han dynasties sites found around the Shahe ancient bridge site

a convenient route allowing the emperors of the Qin and Han dynasties to reach their hunting grove, after the evolution of the Han between Chang'an and the southwest Bashu area traffic arteries, this important bridge crossing the river, southwest of Xianyang city of Qin dynasty, Chang'an city of Han dynasty played an extremely important role in economic exchanges and trade, cultural exchanges, etc.

\section{Microscope slice observations}

The surface of the Shahe ancient bridge sample was dark yellow-brown, the section was charcoal black, and a small number of soil particles were attached. The long strip has a thickness of approximately $0.5 \mathrm{~mm}$, the middle part was slightly recessed inward, and both sides were slightly higher. The texture was weak and fragile (Fig. 4A). The control sample comprised modern fresh bamboo 
(A)

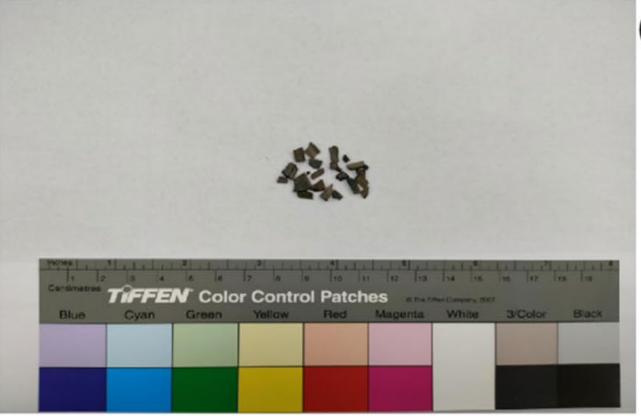

(C)

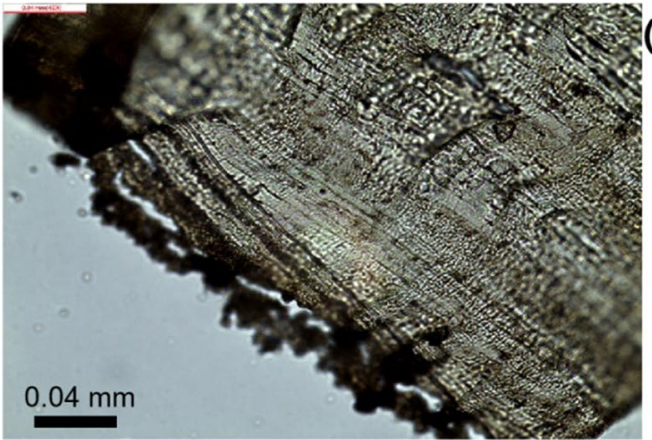

(B)

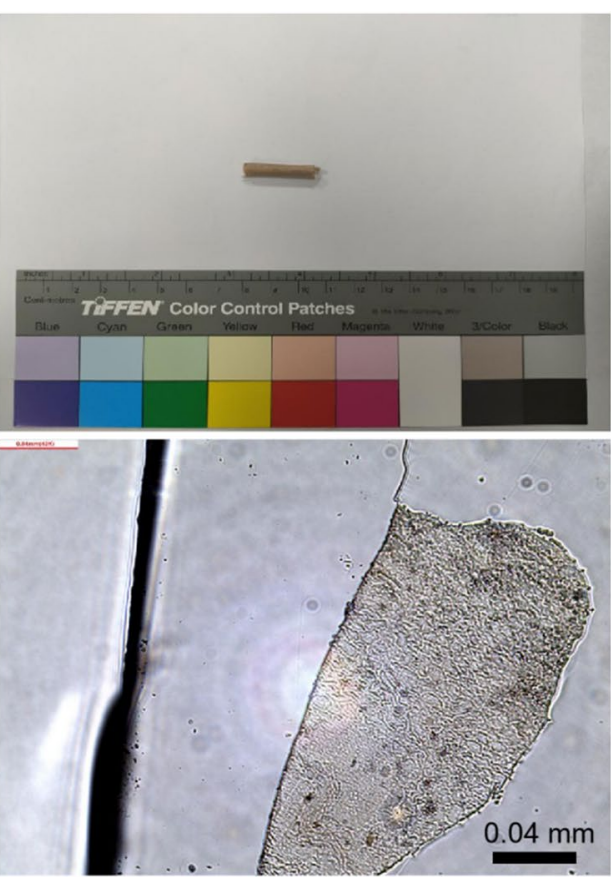

Fig. 4 Fiber structure for the Shahe ancient bridge fascine body sample. A Shahe ancient bridge sample image; B Fresh bamboo sample image; C Longitudinal section microstructure of the Shahe ancient bridge sample; D Transverse section microstructure of the Shahe ancient bridge sample

branches (Fig. 4B). As shown for the microstructure of the longitudinal section of the Shahe ancient bridge sample in Fig. 4C, no wood anatomical structures, such as wood rays, and ducts, were observed. It exhibited a typical vascular bundle structure with parallel solid beams on the periphery; there were irregular in shape and of uneven thickness, and they may have come from thickwalled fibers. As shown in Fig. 4D, there were some well-preserved parenchyma cells in the in the cross-section of the vascular, bundle, but the fiber bundles were connected into one piece and there were breaks, and the middle layer could not be distinguished. The above characteristics are consistent with the anatomical and structural characteristics of bamboo, and the plant samples unearthed at the Shahe ancient bridge ruins are bamboo.

\section{Infrared spectroscopy and X-ray diffraction analysis}

As shown in Fig. 5A, the absorption peak at $1732 \mathrm{~cm}^{-1}$ is derived from the $\mathrm{C}=\mathrm{O}$ stretching vibration of the acetyl group; this is the characteristic of hemicellulose,
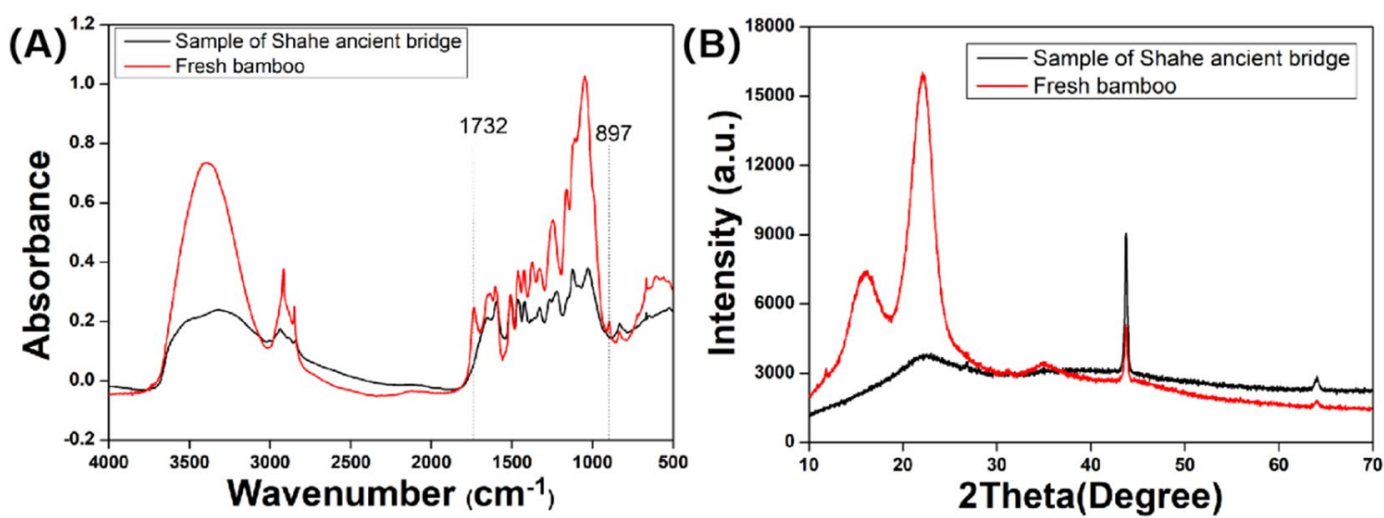

Fig. 5 A Infrared spectra of Shahe ancient bridge and fresh bamboo samples; B diffraction intensities for the Shahe ancient bridge and fresh bamboo samples 
which differs from other components. The peak was not detected in the infrared spectrum of the Shahe ancient bridge sample. Moreover, the cellulose $\mathrm{C}-\mathrm{H}$ bending vibration peak at $897 \mathrm{~cm}^{-1}$ was not detected in the infrared spectrum of the Shahe ancient bridge sample. The above results show that compared with fresh bamboo, the cellulose and hemicellulose of the Shahe ancient bridge sample were both significantly degraded.

XRD was used to determine the crystallinity of the fresh bamboo and Shahe ancient bridge samples (Fig. 5B), using Segal's calculation method:

$$
\begin{aligned}
& \mathrm{CrI}=\frac{\mathrm{I}_{200}-\mathrm{I}_{\mathrm{am}}}{\mathrm{I}_{200}} \times 100 \\
& \mathrm{I}_{200} 2 \theta=22^{\circ} \ldots \mathrm{I}_{\mathrm{am}} 2 \theta=18^{\circ}
\end{aligned}
$$

In the formula, $\mathrm{CrI}$ is the relative crystallinity, I200 is the maximum intensity of the diffraction surface, and Iam represents the intensity of the noncrystalline background diffraction when the $2 \theta$ angle is close to $18^{\circ}$.

Currently, accepted two-phase structural theory holds that cellulose coexists in the crystalline and amorphous phases. The cellulose chains in the crystalline region are arranged in a directional and orderly way, and the lattice is formed by hydrogen bonding on the sides of chains. Generally, as the crystallinity of cellulose in lumber increase, the fracture strength, elasticity modulus, hardness, density, and dimension of lumber rises somewhat, but the extensibility, moisture absorption, run bilge, absorption, toughness, softness and chemical reactivity are reduced somewhat. In the diffraction spectrum of the Shahe ancient bridge sample, the strong diffraction peak at $16.1^{\circ}$ disappeared, which indicated that the unit cell structure of the cellulose crystal area in the Shahe ancient bridge sample has changed during the long-term underground burial process. The calculation shows that the relative crystallinity of the fresh bamboo was $65 \%$, while the relative crystallinity of the Shahe ancient bridge sample was $29 \%$, indicating that the degradation of cellulose mainly occurred in crystalline areas during long-term underground burial of the Shahe ancient bridge sample.

\section{Thermogravimetric analysis}

Figure 6A shows that the pyrolysis process for the Shahe ancient bridge sample can be divided into 4 stages. The first stage covered room temperature to approximately $200{ }^{\circ} \mathrm{C}$; at this stage, only water was separated out, and the extent of weight loss was small. There was a small weight loss peak at $109{ }^{\circ} \mathrm{C}$, which was within the drying stage. The second stage covered $200-220{ }^{\circ} \mathrm{C}$ and exhibited no obvious weight loss, and small amounts of depolymerization, restructuring and glass transition occurred inside the sample, which constituted the prepyrolysis stage. The third stage was approximately $220-410^{\circ} \mathrm{C}$ which was the main reaction stage. This stage mainly exhibited mass losses caused by the pyrolyses of cellulose, hemicellulose and lignin, and the mass change in this stage accounted for approximately $84 \%$ of the total process. The fourth stage was the residue pyrolysis stage, and the temperature range was $450-900{ }^{\circ} \mathrm{C}$. In this stage, the TG curve declined slowly, mainly due to lignin cracking, and entered the slow weight loss stage.

As shown in Fig. 6B, the DTG curve for fresh bamboo had a shoulder peak at $316^{\circ} \mathrm{C}$. Since hemicellulose starts to decompose in a large amounts below $350{ }^{\circ} \mathrm{C}$ cellulose mainly decomposes at $315-400{ }^{\circ} \mathrm{C}$, and the pyrolysis peak for lignin only appears after $400{ }^{\circ} \mathrm{C}$, so this shoulder peak mainly corresponded to the decomposition of hemicellulose. The shoulder peak did not appear in the Shahe ancient bridge sample, indicating that the hemicellulose was poorly preserved in the Shahe ancient bridge sample.
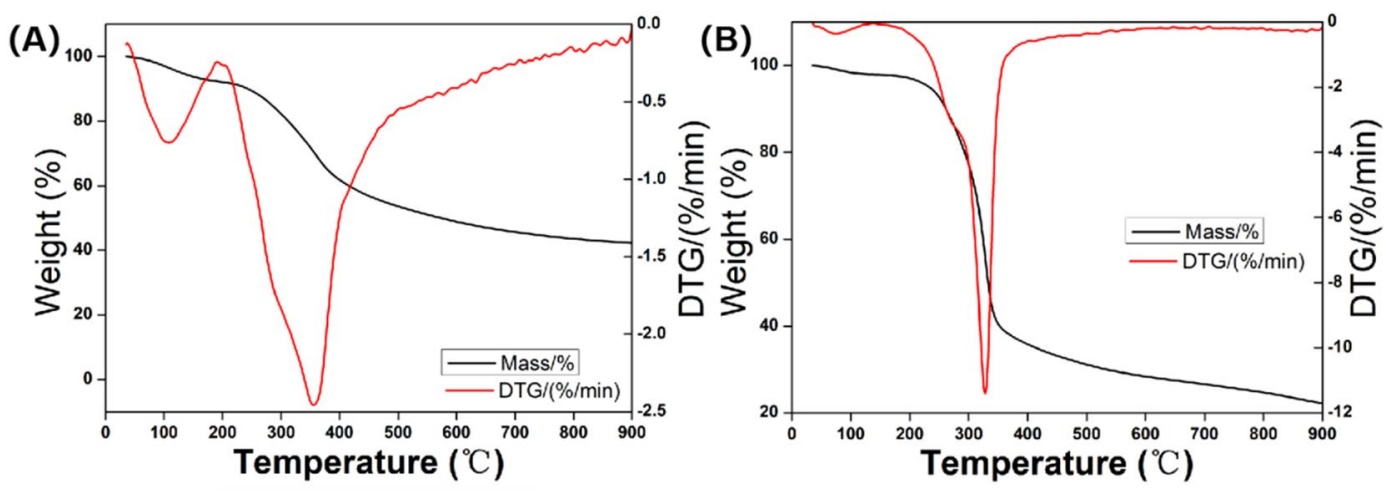

Fig. 6 A TG/DTG curves of Shahe ancient bridge sample; B TG/DTG curves of fresh bamboo 


\section{SEM analysis}

Bamboo wood was used as a flood control material and was deposited along with the sand and gravel in the riverbed. After long-term deposition, the surface retains the form of bamboo, but the inside has been carbonized. It can be seen from Fig. 7A and B show that the surface and cross-sectional morphology of the bamboo carbonized layer exhibited a completely carbonized hard and dense layered structure. The thickness of the carbonized layer with a certain regularity was $2-4 \mu \mathrm{m}$, and it is speculated that the layered structure was caused by the growth rings of bamboo [22]. Fibre, carbonization is very good effect in preventing microbial degradation. Compared with other woods, bamboo contains a higher contents of starch, sugar, and protein and relatively fewer extractives, such as resin, wax, and tannin, so it is more susceptible to microbial erosion; degradation occurs, and the preservation is worse. The collected samples exhibited traces of fine fibres in the gaps between the carbonized layers, as shown in Fig. $7 \mathrm{C}$ and D. Presumably, due to the partial carbonization of the surrounding fibres, the preservation of the fine fibres were much better preserved.

\section{EDX spectrum analysis}

Figures $8 \mathrm{~A}$ and $\mathrm{B}$ showed the energy spectra for the carbonized layer of the bamboo sample and the bamboo fibre, respectively. The main components of the carbonized layer were $\mathrm{C}$ and $\mathrm{O}$, their component contents were $65.72 \%$ and $33.24 \%$, respectively; there are very small amounts of $\mathrm{Mg}, \mathrm{Al}, \mathrm{Si}, \mathrm{Ca}, \mathrm{Mn}, \mathrm{Fe}$ and other trace elements. The element types are basically similar in the fibre layer. Its main components were $\mathrm{C}$ and $\mathrm{O}$, and the contents were $64.63 \%$ and $28.18 \%$, respectively. Ca element in the sand and the Fe element in the unearthed iron relic were removed to the intercell spaces and cavities during the growth of the wood, casting a small amount of metal ions on the wood. The increased contents of $\mathrm{Ca}$ and $\mathrm{Fe}$ elements are thought to be caused by the pollution from sand on the surface.

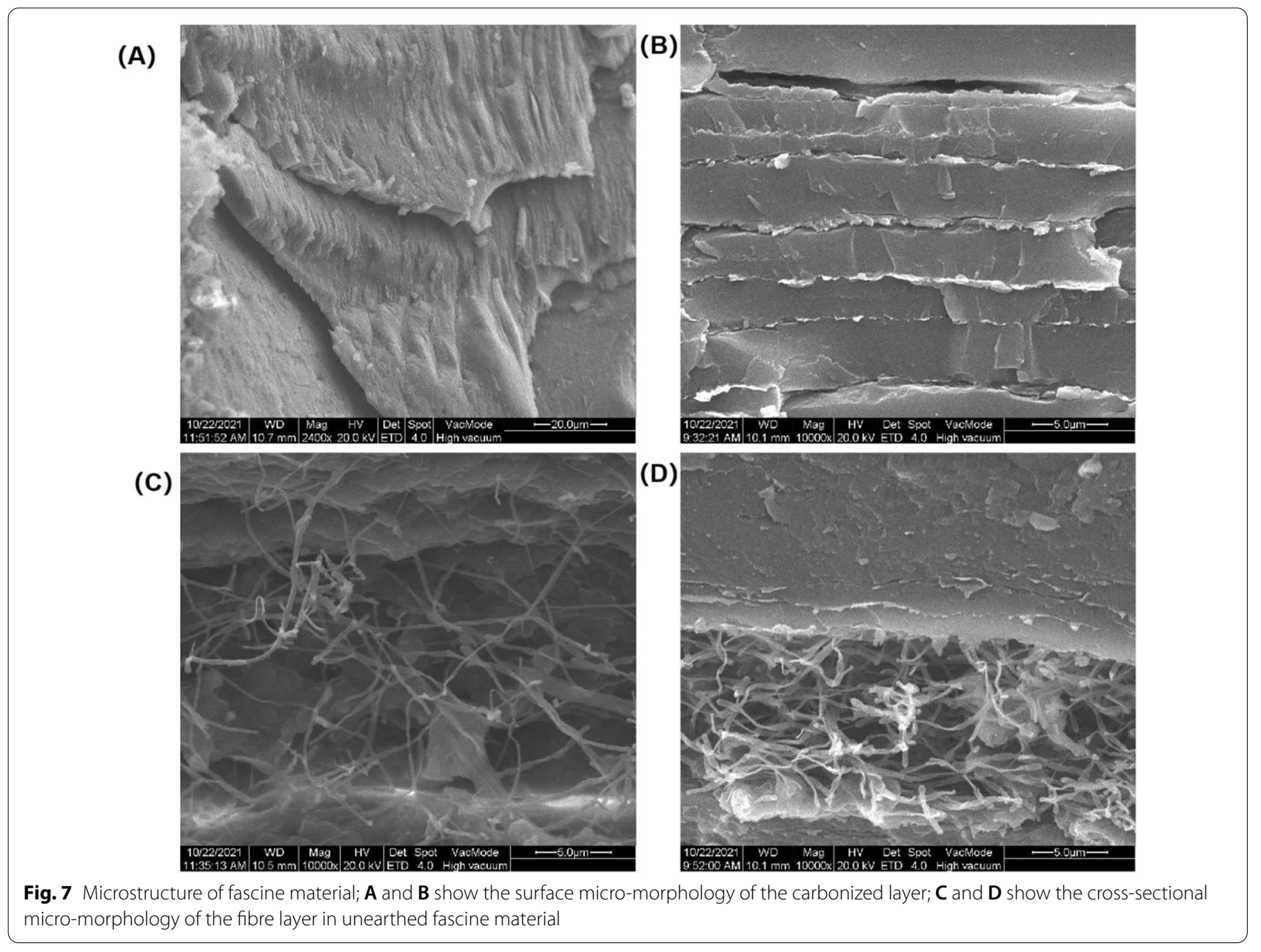


(A)

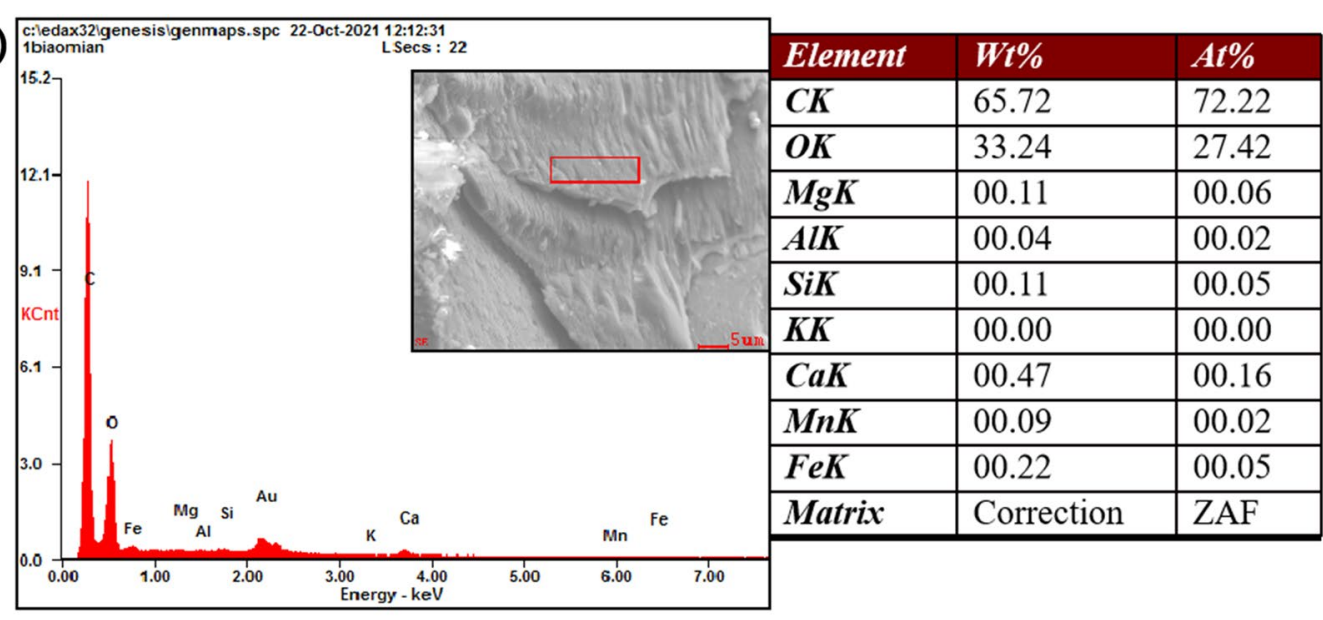

(B)

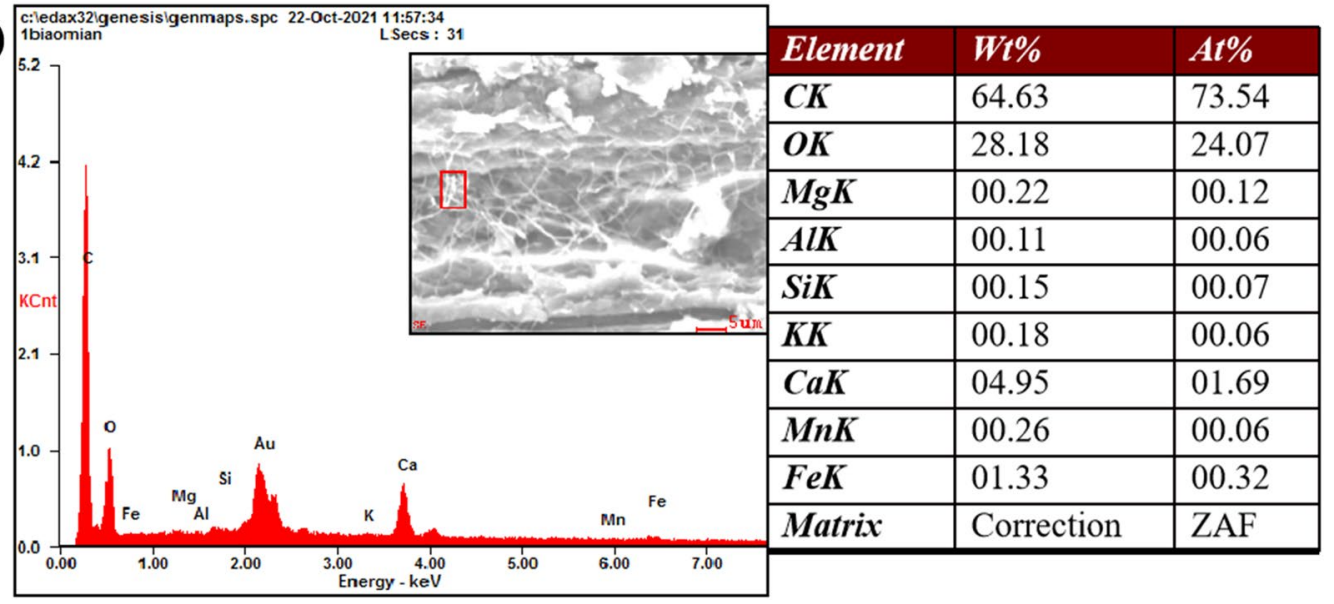

Fig. 8 EDX spectral analyses for the carbonized layer $(\mathbf{A})$ and fibre surface $(\mathbf{B})$ of the bamboo sample

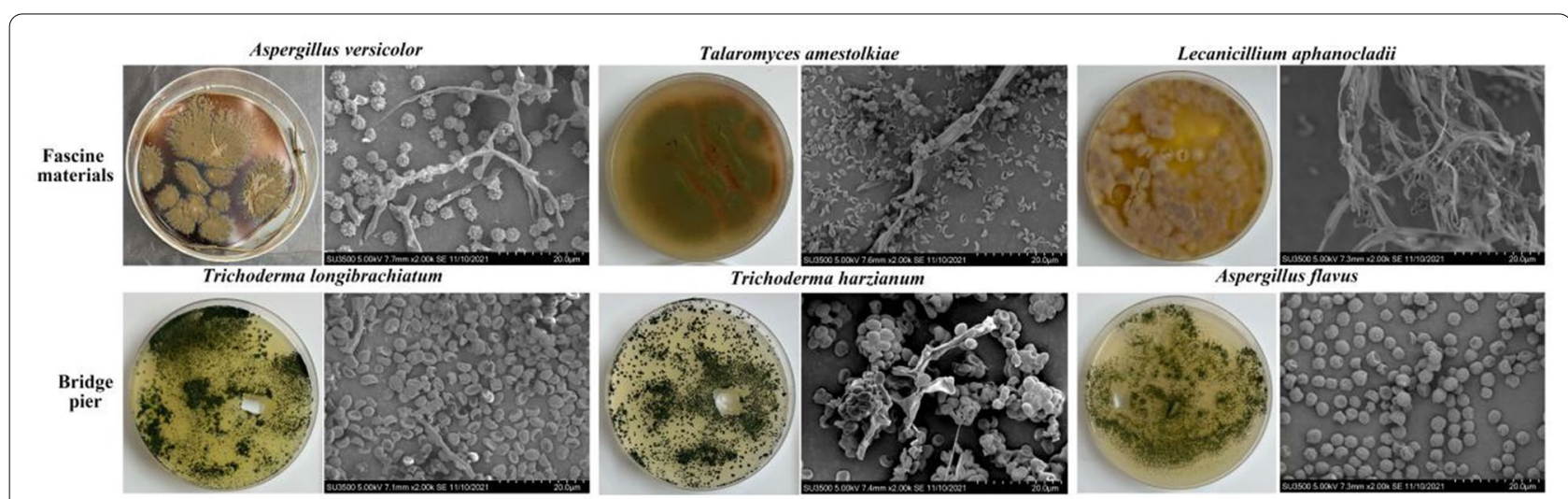

Fig. 9 Isolation and identification of dominant microorganisms from fascine material and the bridge pier 


\section{Microbiological analysis}

Microbial communities were used to determine similarity or dissimilarity between different sample groups and analyses of the relationships between microbial communities and the environment [23]. The results for internal transcribed spacer identification showed that the dominant microbial populations for the fascine material and the isolated bridge pier fungi differed, as shown in Fig. 9. The microbial population of the bridge piers mainly included Trichoderma longibrachiatum, Trichoderma harzianum and Aspergillus flavus. SEM and colony morphologies were consistent with the ITS results. Fascine materials microorganisms were mainly Aspergillus versicolor, Talaromyces amestolkiae, and Lecanicillium aphanocladii. and the results were consistent with colony observations and SEM. The results above showed that the microorganism populations differed for the fascine material and bridge pier, reminding us of the independence of the environments for the fascine material and bridge pier.

\section{Conclusion}

Rivers are key components of the development of civilizations. The protection of the Shahe ancient bridge site "Fascine Bank" is of great value and significance to the studies, of the culture in the Qin and Han dynasties and the ancient Silk Road, and fascine banks also made great contributions to the ability of human beings to transform rivers. In analysing the fascine materials of the Shahe ancient bridge, it was found that samples of the Shahe ancient bridge exhibited typical characteristics of vascular bundles and specially arranged fibres and parenchyma, which were identified as bamboo, Infrared spectroscopy, X-ray diffraction, thermogravimetric analyses, SEM and energy spectrum display analysis showed that the cellulose and hemicellulose of the Shahe ancient bridge sample were degraded seriously, and the cellulose degradation mainly occurred in the crystalline areas. Microbiological analyses established the environmental difference between the fascine material and the bridge pier, and allowed effective selection of materials targeted for anti-mould reinforcement. Excavation of the "fascine bank" ruins determined the bridge width and length boundary of the Shahe bridge, which provided important clues for research on the traffic and layout around Chang'an City during the Qin and Han dynasties and provided a scientific basis for systematic research ob the Shahe ancient bridge.

\section{Acknowledgements}

The authors would like to thank the Jingzhou Preservation Center of Cultural Relics and Shahe Ancient Bridge Site Cultural Relics Administration for their support and research cooperation and thanks the Tang Hanguang Gate Museum for sharing its monitoring data and experience with the ruins.

\section{Authors' contributions}

The manuscript was prepared through contributions of all authors. BM planned the study together with $J C$ and $\mathrm{NL}$, conducted all data analysis, and wrote most of the manuscript. AC, JW, YL, DL, and JL contributed to the collection of samples in the article. All authors read and approved the final manuscript.

\section{Funding}

This work was supported by the National Natural Science Foundation of China (No. 22102094), the Fundamental Research Funds for the Central Universities (No. GK 202103061, GK 202103058) and the Key Research and Development Program of of Shaanxi Province, China (No. 2021SF-457).

\section{Availability of data and materials}

The datasets used and/or analysis results obtained in the current study are available from the corresponding author on request.

\section{Declarations}

Competing interests

The authors declare that they have no competing financial interests.

\section{Author details}

${ }^{1}$ Engineering Research Center of Historical and Cultural Heritage Protection, Ministry of Education, School of Materials Science and Engineering, Shaanxi Normal University, Xi' an 710119, China. ${ }^{2}$ Shaanxi Institute of Archaeology, Xi' an 710054, China. ${ }^{3}$ Fengxi Cultural Relics Bureau of Xixian New District, Xianyang 712000, China.

Received: 17 November 2021 Accepted: 29 January 2022

Published online: 14 February 2022

\section{References}

1. Cao J, Mai B, Chen H, Li Y, Wang J. Geotechnical investigation for the groundwater damage analysis of the Shahe Ancient Bridge Site in Xi'an, China. Herit Sci. 2021;9:9. https://doi.org/10.21203/rs.3.rs-141276/v1.

2. Wilhelm B, Cánovas JAB, Macdonald N, et al. (2018) Interpreting historical, botanical and geological evidence to aid preparations for future floods. WIREs Water. 2019;6: e1318. https://doi.org/10.1002/wat2.1318.

3. O'Shea TE, Lewin J. Urban flooding in Britain: an approach to comparing ancient and contemporary flood exposure. Nat Hazards. 2020;104:58191. https://doi.org/10.1007/s11069-020-04181-8.

4. Luberti GM. Computation of modern anthropogenic-deposit thickness in urban areas: a case study in Rome Italy. Anthrop Rev. 2018;5:2-27. https:// doi.org/10.1177/205301961875252.

5. Duan L, Duan L, Ma J. Base on the new technique for rescuing the Yellow River, "Dumpling net" is studied and applied to the base. Henan Water conservancy and South-to-North Water Transfer. 2015;14:121-2.

6. Fu L, Hu S. Base on the Yellow River, casting the work is brief. People Yellow River. 1984;04:41-4.

7. Evette A, Labonne S, Rey F, Liebault F, Jancke O, Girel J. History of bioengineering techniques for erosion control in rivers in Western Europe. Environ Manage. 2009;43:972. https://doi.org/10.1007/s00267-009-9275-y.

8. Tian M, Zhang S, Su L. Base on the critical condition of the Yellow River, casting is necessary for base casting. Science Technol Inform. 2008;32:369-369. https://doi.org/10.3969/j.issn.1001-9960.2008.32.299.

9. Flatley A, Rutherfurd ID, Hardie R. River channel relocation: problems and prospects. Water. 2018;10:1360. https://doi.org/10.3390/w10101360.

10. Dai L. Study on river mark and river camp in Qing Dynasty. Kunming: Yunnan University; 2015.

11. Li D. On the temporal and spatial evolution of river engineering materials in Ming and Qing Dynasties-Hard materials in Huangyun area as the center. J Liaocheng Univ. 2021. https://doi.org/10.16284/j.cnki.cn371401/c.2010.01.020

12. Ai G, Yun S. Base on the Yellow River, casting is applied to county rescue. Yellow River. 2009. https://doi.org/10.28341/n.cnki.nhhbz.2009.000133. 
13. Sun W. The Functional value of "Yellow River Chant" and thoughts on its inheritance and protection. Literary theory and criticism. 2016;02:138-41. https://doi.org/10.16532/j.cnki.1002-9583.2016.02.025.

14. Liu Z, Zhang Y, Zhang F, Hu C, Liu G, Pan J. Microbial community analyses of the deteriorated storeroom objects in the Tianjin museum using culture-independent and culture-dependent approaches. Front Microbiol. 2018;9:802. https://doi.org/10.3389/fmicb.2018.00802.

15. Wang Y, Zhang Z, Fan $\mathrm{H}$, Wang J. Wood carbonization as a protective treatment on resistance to wood destroying fungi. Int Biodeterior Biodegradation. 2018;129:42-9. https://doi.org/10.1016/j.ibiod.2018.01.003.

16 Andrew MS. Flood control initiates Chinese civilization. Science. 2016. https://doi.org/10.1126/science.353.6299.553-c.

17. Michael H. Geosynthetics for waterways and flood protection structures - controlling the interaction of water and soil. Geotext Geomembr. 2014;42:374-93. https://doi.org/10.1016/j.geotexmem.2014.06.003.

18. Yi S, Jun CP, Jo KN, Lee H, Kim MS, Lee SD, Cao X, Lim J. Asynchronous multi-decadal time-scale series of biotic and abiotic responses to precipitation during the last 1300 years. Sci Rep. 2020;10:17814. https://doi.org/ 10.1038/s41598-020-74994-X.

19. Wang Z, Lu J, Yuan Y, Huang Y, Feng J, Li R. Experimental study on the effects of vegetation on the dissipation of supersaturated total dissolved gas in flowing water. Int J Environ Res Public Health. 2019;16:2256. https://doi.org/10.3390/ijerph16132256.

20. Lachat B. Quelques souvenirs historiques et perspectives d'avenir du génie biologique en Suisse romande et en francophonie. Génie biologique. 1999;4:7-14.

21. Voronin K, Kabanova M. Chemical-technological research and radiocarbon AMS dating of wall painting fragments from the ruins of the XIlth-XIllth centuries AD church from archaeological excavations in the city of Smolensk. Russia Herit Sci. 2020;8:45. https://doi.org/10.1186/ s40494-020-00389-w.

22. Rasmussen KL, van der Plicht J, Nasa L, Ribechini E, Colombini PM, Delbey T, Skytte L, Schiavone S, Kjaer U, Grinder-Hansen P, Lanzillotta RL. Investigations of the relics and altar materials relating to the apostles St James and St Philip at the Basilica dei Santi XII Apostoli in Rome. Herit Sci. 2021;9:14. https://doi.org/10.1186/s40494-021-00481-9.

23. Zhang K, Li B, Guo M, Liu G, Yang Y, Wang X, Chen Y, Zhang E. Maturation of the goat rumen microbiota involves three stages of microbial colonization. Animals (Basel). 2019;9:1028. https://doi.org/10.3390/ani9121028.

\section{Publisher's Note}

Springer Nature remains neutral with regard to jurisdictional claims in published maps and institutional affiliations.

\section{Submit your manuscript to a SpringerOpen ${ }^{\circ}$ journal and benefit from:}

- Convenient online submission

- Rigorous peer review

- Open access: articles freely available online

- High visibility within the field

- Retaining the copyright to your article

Submit your next manuscript at $\boldsymbol{\nabla}$ springeropen.com 